Hill River became a church-museum in 1980 with various souvenirs from the past and hosting occasional religious or cultural events. Fr. Rogalski would be happy to know that he had successors: several Polish Jesuits worked in Australia during the last century serving the Polish Catholic community: currently four of them are based in Melbourne.

\author{
Robert Danieluk \\ Archivum Romanum Societatis Iesu, Rome, Italy \\ arsi-danieluk@sjcuria.org \\ DOI:10.1163/22141332-0802P011-05
}

\title{
James E. Kelly
}

English Convents in Catholic Europe, c. 1600-1800. Cambridge: Cambridge University Press, 2020. Pp. viii + 225. Hb, \$99.99.

English Catholics established twenty-one religious houses for women on the continent in the late sixteenth and seventeenth centuries. To this total could be added one community that survived from pre-Reformation England and Mary Ward's Institute that sought to adapt the Jesuit way of proceeding to women. The idiosyncratic followers of Mary Ward, subjected to furious attack as proxies for English Jesuits who were blamed for misleading these innocent women, were officially suppressed in 1631. They survived, however, in Munich, St. Omers, and Liège, but for all practical purposes play no role in this monograph because Ward's Institute "deservedly spawned a whole research sub-section of its own" (7). Between 1600 and 1800 when the majority of the houses were closed because of the wars of the French Revolution and the inhabitants sought refuge in a more tolerant England, nearly four thousand women, overwhelmingly English, belonged to these congregations. The girls educated in these communities numbered in the hundreds. Until Caroline Bowden and James Kelly pioneered the "Who Were the Nuns?" project, most of the nuns were unknown, shadowy figures floating and obscured by a grille. The project, in a phrase of David Cressy, "dislodged from obscurity" the nuns by removing the lattice to reveal the lives and spiritualities behind it.

The Society of Jesus and especially the English mission/province play major supporting roles in the monograph. Kelly frequently notes the importance of the Jesuit network for the transfer of aspirants and funds from England to the continent, and subsequent correspondence between the nuns and their families. In 1598, the mission's Jesuit superior Henry Garnet estimated that English Jesuits had aided the transfer of twenty candidates 
to the Augustinian convent in Leuven and often absorbed the cost of doing so (24). Later, in 1629, that convent turned to an English Jesuit at St. Omers for advice and assistance in their efforts to open a new convent in Bruges. These Augustinian convents also had noticeable Jesuit connections in their benefactors, confessors, and families that produced vocations. The same was true of the Benedictine convent in Brussels until the 162 os when the abbess repudiated Ignatian spirituality and barred Jesuit confessors with consequent repercussions on communal life and domestic harmony. How compatible were Ignatian spirituality and monastic life? The conflict that one would anticipate between monastic enclosure and apostolic mobility merits further investigation. Ignatius's spirituality may have been rejected by some convents, but his thaumaturgic qualities were appreciated: pieces of his cloak eased the pain of childbirth, and of his cassock cured illnesses $(146-47)$. His and Francis Xavier's relics as well as Ignatius's water were popular. Regarding Jesuits, I have a small correction: the Englishman John Bolton working in the United States in 1786 was technically a former or ex-Jesuit because of the suppression in 1773 (63-64).

The Society's Constitutions explicitly forbade Jesuits from serving as regular confessors or spiritual directors to convents of nuns. Thus, the appearance of specific Jesuits in these roles is curious and problematic. English Jesuits resolved this imbroglio through institutional and not personal commitments, or by claiming they were irregular or extraordinary confessors, a distinction frequently lost on Belgian Jesuits. Regardless of the frequency Jesuits were not always the benefactors but occasionally recipients or colleagues. The Augustinian convent in Bruges contributed to the rebuilding of the English Jesuit college in St. Omers after the fire of 1726 in appreciation of the spiritual aid it had received from the college over the years. Similarly, the convent assisted the former Jesuits after the Society's suppression in 1773. The Sepulchrines and English Jesuits in Liège collaborated liturgically, musically, and spiritually.

Cloister did not protect the nuns from the problems troubling English Catholics as they struggled over the appointment of a bishop or from attempts by the male branches of their orders to dominate and control them. Certain convents were Jesuit-friendly; others were markedly opposed. In 1619, the Poor Clares at Gravelines used rules of enclosure and cloister to bar admission to English Franciscans determined to exercise authority over the convent (76).

English? Catholic? Which adjective better describes the convents? Were they English ghettos, enclaves, immured and immune from their continental setting? Or did they engage in the wider world of transnational, early modern Catholicism? Caroline Bowden proposed the convents as "transnational 
textual communities; they were self-consciously English, yet they operated within a European Tridentine culture" ("Building Libraries in Exile: The English Convents and Their Book Collections in the Seventeenth Century," British Catholic History 32 [2015]: 343-82, here 350). There is no scholarly consensus on this point. Al Loomie, S.J., observed that "religion did not prove to be a convenient bond in any degree for those who were opposed, for various reasons, to the politics of the English Court" (The Spanish Elizabethans: The English Exiles at the Court of Philip II [New York: Fordham University Press, 1963], 231). Claire Walker makes a similar point: the nuns "saw themselves primarily as members of the English Catholic community, and only secondarily as members of the universal Catholic Church" (Gender and Politics in Early Modern Europe: English Convents in France and the Low Countries [Basingstoke: Palgrave Macmillan, 2003], 40-41). Kelly supports Bowden and insists-indeed, the argument drives the monograph - that "Catholicism, a characteristic that trumped all others, dictated their very identity" (10). Thus, he challenges a historiography "that prioritises their position as communities of women or interprets them through a lens of nationality, considering them simply as communities of English" (191). Yet Kelley is not naive. "Notionally," he observes, "the English convents should have been united with not just English, but also Scottish and Irish exile institutions in a spirit of Catholic missionary zeal" (182), and admits occasions when "national identities won out over confessional ones [...] [as] the exile institutions became focal points for expatriate communities, fulfilling various social, educational and political functions not normally associated with religious foundations" (184). Kelly and Bowden reset the English convents within international Catholicism as a balance to a common overemphasis on their Englishness. Perhaps it is only a question of degree as the nuns negotiated between English and non-English preoccupations and perceptions, but it is essential that academia be reminded periodically that social activism or national sentiment does not explain why they abandoned so much for the cloister. Convents were more than a haven for more confessionally mobile English Catholics. Kelly is to be congratulated for restoring the religious dimension to the discussion.

Thomas M. McCoog, S.J.

Loyola University of Maryland, Baltimore, MD, USA

tmmccoog@gmail.com

DOI:10.1163/22141332-0802P011-06 